\title{
The Emerging Islam in America
}

DOI 10.18196/AIIJIS.2020.0125.288-293

\section{SHOLAWATI}

PMSI Universitas Muhammadiyah Yogyakarta

$\begin{array}{ll}\text { Book Tittle } & \text { : Geliat Islam di America } \\ \text { Author } & \text { : Prof. Dr. K.H. Nasaruddin Umar, M.A. } \\ \text { Publisher } & \text { : Amzah } \\ \text { City } & \text { : Jakarta } 13220 \\ \text { Publication Year } & : \text { : } 2020 \\ \text { Number of Page } & : 218 \\ \text { ISBN } & : 978-602-0875-92-7\end{array}$

Islam has an essential role in the development of human civilization. As a relatively new religion, Islam has developed very rapidly for over 1500 years. Currently, Islam is recorded as the second-largest religion in the world after Christianity, with followers of more than 1.5 billion. Based on several official survey institutions, in 2025, it is predicted that Muslims will reach $30 \%$ of the earth's population and become the largest religion in the world. ${ }^{1}$

Islam was born in the Arabian Peninsula and has spread throughout the world. Muslims can be found in almost all countries, including underdeveloped countries, developing countries, and developed countries. Even the United States, with the most substantial economic, political, and military power globally, is inseparable from Muslims in its development process. Edward E. Curtis, in his book Muslim Americans in The Military, mentioned various historical evidence showing Muslim participation in America. According to this Professor of Religion from the University of Indianapolis, Muslims had played a significant role, from discovering the Americas to defending the north's victories in the United States Civil War. ${ }^{2}$ Also, he added that even though Christopher Columbus was the sailor who discovered America, that discovery would be impossible to happen without Muslims.

Ironically, starting in the 20th century, there was an anti-Muslim sentiment in America and worsened by the bombing of the WTC building on 
September 11, 2001, known as the 9/11 incident. The tragedy was carried out by a handful of people who acted in Islam's name, had provoked both fear and hatred of the public towards Islam. There is a lot of discrimination against Muslims in America, as reported by several international media. This discrimination had an impact on Muslims in other countries, especially Indonesia, which later became anti-American. America is considered an anti-Islamic country and has a significant share in the never-ending wars in Islamic countries in the Middle East. ${ }^{3}$

The above assumption is not entirely correct since it does not represent America as a whole, as stated by the professor of UIN Syarif Hidayatullah Jakarta, Nasaruddin Umar, in Geliat Islam, about how Muslims in America are. Regardless of the occurring Islamophobia, Islam is proliferating in America. In fact, he repeatedly quoted Hillary Clinton's speech, which stated that "Islam is the fastest-growing religion in US America." The number of Muslims in America continues to grow every year. The phenomenon eliminates prejudices and assumptions about America being anti-Islamic. ${ }^{4}$

This book by Nasaruddin contains 18 chapters. It started from a brief description of the history of the United States' formation and the involved Muslim figures. Nasaruddin denies the notion that America is a secular country. He mentioned the phrase "One Nation under God," which was included in the (Pledge of Allegiance) of the United States. According to him, the pledge proves that America is not entirely anti-religious. The next chapter about the influx of Muslim immigrants from African countries is quite large in the 19th century. Muslims from various countries are interested in living in America because America is a free country, prioritizing recognition and respect for human rights so that Muslims can live peacefully and carry out religious practices without any intervention.

Nasaruddin said that as a free country, America is a country with good tolerance. He quoted an article from Prof. Osman Bakar, entitled "The Intellectual impact of American Muslim Scholars on the Muslim World, with Special References to Southeast Asia," which calls America "The Second Mecca." This view is based on the fact that there are various ethnic and Muslim components from Africa, Arab, Persian, South Asia, Southeast Asia, and different other parts of the world in Mecca. Muslims in America perform their respective schools and traditions. There are those with Hanafi, Maliki, Syafi'i, and Hanbali schools of thought in figh. Some belong to rational and conservative theology. Some are Sunni, Syi'ah, Wahabi, and various kinds of tarekat. Al- 
though they come from multiple types of sects and schools of thought, they carry out their worship according to their respective beliefs and maintain mutual tolerance toward other Muslim groups.

In several parts, Nasaruddin does not only describe the harmony that occurs between Muslim groups of different sects. But balance also occurs between followers of other religions. Abrahamic Religion's phenomenon or beliefs were born from the grandchildren of the Prophet Abraham, Judaism, Christianity, and Islam. These religions, which usually conflict with open wars in other countries, get along very well in America. They invite each other if there is a special event or important moments. It is not uncommon to find families with members of different religions. Freedom in America supports these things. Religious people who feel like minorities support each other and display excellent religious behavior, especially Muslims who always campaign for Islam as rahmatan lil Alamin, full of compassion for everyone.

The stigmatization of Islam as a radical, anti-tolerant religion has been refuted because the Muslim community in the United States is a professional group. This is different from Muslim minority groups in other countries, which are dominated by manual labor. In America, in general, Muslims are professionals, intellectuals, and educated. The American Muslim community falls into the upper-middle category or Middle Up. Of course, Muslim groups like this are more considered by the state. This Muslim group then also built various Islamic organizations, which were quite influential in building America.

Nasaruddin Umar said that in America, there are various types of Islamic organizations. The Islamic organization strives to create a harmonious and peaceful life for the Muslim community in its environment, regardless of the origin of the country or different schools. Muslims in America can build cooperation and live side by side without any significant problems within the organization. Tolerance is very well made. Islamic organizations also provide various services, for example, in the fields of education, economics, health, and so on.

For example, these Islamic organizations (AMC founded in Chicago in 1990) are engaged in empowering Muslims, including fighting for their rights through political channels. The Council on American-Islamic Relations (CAIR) is also one of the major Islamic organizations in Washington, DC. This organization aims to provide advocacy for Muslim communities who often do not understand their civil rights and obligations as citizens of the United States. 
There are more than thirteen Islamic organizations mentioned by Nasaruddin Umar in his book. These organizations help the American government provide education for the Muslim community in complying with the rules applicable in the United States. They also promote inter-religious and inter-ethnic tolerance in America. These organizations also teach about universal Islamic values, which are paralleled with the importance of independence that America upholds.

An influential organization for Muslims living in America is CAMRI (Center for American Muslim Research and Information). This institution is responsible for conducting thorough and in-depth research, checking, and investigating various products and ingredients directly to food companies. In other words, this institution helps provide halal food, which is one of the necessities that may be difficult to find in America.

In general, this book by Nasaruddin Umar gives us essential information that America is a very suitable country for Muslims to live in. Even though being a minority is definitely more difficult than being the majority as in Indonesia. The image of Muslims who have the most expansive freedom possible, as with followers of other religions, gives us a new perspective that America is not genuinely anti-Islam. In this case, I agree with what the author said. It's just that this book was written with an extended emphasis on the positive aspects of America. The negative aspects are not addressed. Thus, there is potential for discrepancies and differences between the reality on the ground and the book's contents.

For example, various facts or events covered by mixed mass media such as National Geographic Indonesia. ${ }^{5}$ The occurrence of oppression of Muslim children in America is increasing rapidly, which is generally caused by cultural and religious misunderstandings. Then, the mosque's burning on January 28, 2017, which several hours earlier, President Donald Trump issued an executive order banning entry to people coming from seven Muslim-majority countries. President Donald Trump, who was elected and officially sworn in on January 20, 2017, once proposed banning Muslims from entering America to improve domestic security. The American president said clearly, "I am establishing new scrutiny measures to guard the US against the outside threat of radical Islamic terrorists. We only want to include people into our country who will support our country and love its citizens... "This is not discussed further in the book by Nasarudin Umar, which is clearly titled" Geliat Islam."

The book Geliat Islam's discussion in the United States focuses on positive 
things, such as President Donald Trump inviting Muslim figures to break the fast together at the White House, even though that is only an excuse in the context of diplomacy. Or how about President Barack Husein Obama, who once lived in Indonesia where the environment is predominantly Muslim, or when giving a speech at Cairo University stating to solve the problem of radicalism and terrorism with a soft power approach. Or information about Muslims, the majority of whom are professional groups, but forget the fact that many Muslim women have been fired from companies for refusing to remove their hijab.

In my opinion, this book was written not through long research; some parts are unedited copies of Wikipedia. For example, regarding Malcolm X., some features do not explain the exact time and place when and where the situation occurred. It would be impossible to make the reader believe that this condition really happened in America with a considerable area. In my opinion, the delivery is not systematic enough; several things are being repeated. For example, such as the statement "America is a country with an exemplary level of tolerance, America is very open to Islam and its adherents," or the Pledge of Allegiance, which is written many times, and various repetitions that I think are unnecessary.

\section{ENDNOTE}

1 Moeflich Hasbullah, "Islam di Amerika : Sebuah Keajaiban Bernama 9/11", ePaper Pikiran Rakyat, 28 Februari 2008, akses 9 Mei 2020, 12:57:37AM pada https://www.academia.edu/3668805/Islam_di_Amerika_Sebuah_Keajaiban_Bernama_9_11?auto=download

2 Edward E Curtis IV, Muslim Americans in The Military: Centuries of Service, (Bloomington, : Indiana University Press, 2016)

3 Nashih Nasrullah, "Alasan Mengapa Amerika Ambisi Perangi Timur Tengah", Repubilka News, akses 8 Mei 2020 15:10:31AM pada https://republika.co.id/ berita/qbcd9k320/alasan-mengapa-amerika-ambisi-perang-di-timur-tengah

4 Nasaruddin Umar, Geliat Islam di Amerika Serikat, (Jakarta : Amzah, 2020)

5 Rahmad Azhar Hutomo, "Kisah Muslim Di Amerika, Kerap Ditindas Tapi Semakin Berkembang”, National Geographic Indonesia, edisi Minggu 3 Maret 2019, akses 6 Mei 2020 12:30:31AM pada https://nationalgeographic.grid.id/ $\mathrm{read} / 131652089 /$ kisah-muslim-di-amerika-kerap-ditindas-tapi-semakinberkembang?page $=$ all

\section{REFERENCE}

Curtis, E. E. (2016). Muslim Americans in The Military: Centuries of Service. Bloomington Indiana Universiry Press. 
Hasbullah, M. (2008). Islam di Amerika: Sebuah keajaiban bernama 9/11. E-paper Pikiran Rakyat. https://www.academia.edu/3668805/Islam_di_Amerika_Sebuah_Keajaiban_Bernama_9_11.

Hutomo, R. A. "Kisah Muslim di Amerika, Kerap Ditindas Tapi Semakin Berkembang”. National geographic Indonesia. edisi Minggu 3 Maret 2019. https:/ /nationalgeographic.grid.id/read/131652089/kisah-muslim-di-amerika-kerapditindas-tapi-semakin-berkembang?page=all

Nashrullah, N. 2020. "Alasan Mengapa Amerika Ambisi Perangi Timur Tengah". Republica News. https://republika.co.id/berita/qbcd9k320/alasan-mengapaamerika-ambisi-perang-di-timur-tengah

Umar, N. (2020). Geliat Islam di Amerika Serikat, (Jakarta : Amzah, 2020). 